\title{
NUTRITIONAL STATUS AMONG PRIMARY SCHOOL GOING CHILDREN LIVING IN URBAN AREA OF SINDH PAKISTAN
}

\author{
Muhammad Faisal Qureshi ${ }^{1}$, Aneeta Rathore ${ }^{2}$, Nandlal Seerani $^{3}$, Sumera Qureshi ${ }^{4}$, Dr.Bisharat Faisal $^{5}$ \\ and Ramesh Kumar
}

${ }^{1}$ Fellow at Health Services AcademyandMedical Officer, Sindh Government Hospital Qasimabad, Hyderabad.

${ }^{2}$ Assistant Professor, Hazarat Bari Sarkar Medical College Islamabad.

${ }^{3}$ Assistant Professor, LUMHS Hospital Hyderabad/Jamshoro.

${ }^{4} \mathrm{Ph} . \mathrm{D}$ fellow at Institute of Chemistry, University of Sindh, Jamshoro.

${ }^{5}$ Post graduate trainee, LUMHS Hospital Hyderabad/Jamshoro.

${ }^{6}$ Assistant Professor, Department of Health System \& Policy; Health Services Academy, Islamabad.

Correspondence: NandlalSeerani.Email: lal_nand76@hotmail.com

\begin{abstract}
Background: Children's health is very important for their better learning and timely nourishment everywhere in the world. Malnutrition among school going children has remained a big challenge in under developed countries.

Methods: Cross-sectional study was conducted among 422 children of four Government Primary schools of Qasimabad, district Hyderabad after taking the proper consent and administration approval from the head of school. Multi stage simple random sampling technique was adopted. Study was approved from Institutional review board of Health Services Academy Islamabad.

Results: Out of total, 217 (51.4\%) were boys and 205 (48.6\%) were girls. Mean Height of boys and girls were $128.09 \mathrm{~cm}( \pm S D 12.90)$ and $130.36 \mathrm{~cm}( \pm S D 12.50)$ respectively. Mean Weight of boys was $25.27 \mathrm{Kgs}( \pm S D$ $6.17)$ while in girls mean Weight was $26.83 \mathrm{Kgs}( \pm S D$ 7.03). $17.57 \mathrm{~cm}( \pm S D 2.34)$ was mean MUAC for all participants and mean BMI was 15.42 ( \pm SD 2.02). Prevalent of stunting and wasting were $24.4 \%$ and $18.3 \%$ respectively. While in $13.7 \%$ thinness (BMI for age) was seen. Stunting was statistically significant in girls $9-10$ year ( $\mathrm{p}$ value $=.015, \mathrm{Cl}$ : .118-.823, OR=.311) and $11-\geq 12$ years ( $\mathrm{p}$ value=.018, Cl: .215-.874, OR=.434). Pallor was more in girls $(17 \%)$ and Dental caries were higher in boys $(20.8 \%)$. Insufficient breakfast was done by 347 $(82.2 \%)$, whereas $75(17.8 \%)$ were doing sufficient breakfast. $341(80.8 \%)$ students became ill during last year, out of that $80(19 \%)$ were having history of hospitalization.

Conclusion: Poor polices and lack of food aid interventions regarding health of primary school going children was assessed during this study.
\end{abstract}

Key Words: Stunting, wasting, thinness, children, government primary schools

\section{Introduction:}

Children health is very important during their growth period. The school age period is nutritionally significant because this is the prime time to build up body stores of nutrients in preparation for rapid growth of adolescence.Malnutrition remains the world"s most serious health problem and the single biggest contributor to child mortality, nearly one third of the children in the developing world are either underweight or stunted. The health status of an adult is also depending on his childhood nutritional status [1]. Malnutrition is defined as different forms of poor nutrition leading to both underweight and overweight conditions caused by a complex array of issues, including dietary inadequacy, infections, and sociocultural factors. Good nutrition builds a stronger immune system, better health and productivity. Malnutrition can lead to deficiencies of macro and micronutrients, wasting and stunting, and other diseases [2,3].The underlying factors like; clean drinking water, food security, education, good sanitation conditions and heath care services contribute to improve nutritional status in an individual and communities. These are caused by an association of dietary deficiencies; poor maternal and child health and nutrition; a huge burden of morbidity; and low micronutrient content in the soil, especially iodine and zinc. Many of these micronutrients have profound effects on immunity, growth, and mental development [4].

Primary school going children need more attention regarding to their physical and mental growth and it is the neglected group to do any food aid programme implemented by government or donor agencies. Principal aim of study was to improve nutritional status of primary school going children, with 
prevalence of stunting and underweight in primary school going children.

\section{Methodology:}

A cross sectional study was conducted in Hyderabad Sindh by adopting the multistage cluster sampling. In first stage four government primary schools (GPSs) were selected randomly in taluka Qasimabad, district Hyderabad provided. In second stage students of primary section studying in class first to fifth standard were selected randomly selected. After written consent, signed by their parents /class teacher, a detailed interview was conducted on World Health
Organization (WHO) adopted, pretested, validated questionnaire. Each questionnaire was consisting socio-demographic profile, Physical examination, anthropometric measurements, dietary practices and health profile regarding last year illness. Data was collected after a training of data collectors by Principal investigator prior to start the study. Ethical consideration was taken from Institutional Review Board (IRB) of Health Services Academy Islamabad.

Results: A total of 422 students were selected from four GPSs of Qasimabad. 217 (51.4\%) were boys and $205(48.6 \%)$ were girls (Table: 1 )

\section{Table 1: Number and percentage of participants in Government Primary Schools}

\begin{tabular}{llccc}
\hline S No: & Name of school & & & \\
\hline 1 & & Boys (\%) & Girls (\%) & Total (\%) \\
\hline 2 & GPS Shahbaz Town & $83(57.2)$ & $62(42.8)$ & $145(34.3)$ \\
3 & GPS BachalChandio & $30(30)$ & $70(70)$ & $100(23.7)$ \\
4 & GPS Shoro Goth & $50(82)$ & $11(18)$ & $61(14.5)$ \\
\hline Total & GPS Peon Coloney & $54(46.6)$ & $62(53.4)$ & $116(27.5)$ \\
\hline
\end{tabular}

The residential status of $329(78 \%)$ were urban and 93 $(22 \%)$ were belong to rural areas by birth. Parental occupation of $134(31.8 \%)$ students was government servants and parents of $288(68.2 \%)$ students were having private work or earn daily wedges. Government servants mostly were doing job like driver, peon, naibqasid, watchman, police constable and clerk. While parents were laborers, massons, shopkeepers, barbers, milk dispatchers and tea shop (dhaba) owners were categorized in private work. Fathers of $106(25 \%)$ pupils were illiterate and 316 $(75 \%)$ were literate of which $165(52.2 \%)$ had passed their primary, $111(35.2 \%)$ were matriculated and 40 $(12.6 \%)$ were graduated.

Where as literate mother was seen in $190(45 \%)$ of study population among them 166 mothers (87\%) were primary passed, $20(11 \%)$ and $4(2 \%)$ were matriculated and graduated mothers respectively. Remaining 232 (55\%) participant's mothers were illiterate.Most of participants belonged to low and middle socioeconomic class. The mean income per month of participant's father/caregiver was Rs: $14681.27( \pm$ SD 7943.46$)$. The Mean value of Mid Upper Arm Circumference (MUAC) was $17.57 \mathrm{~cm}$ $( \pm S D 2.34)$ in whole study population. Gender wise in boys the MUAC Mean was $17.07 \mathrm{~cm}( \pm S D$ 1.96) and in girls Mean MUAC was $18.10 \mathrm{~cm}( \pm S D$ 2.59).the mean weight of study population was $26.03 \mathrm{Kgs}( \pm S D$ 6.64 ) with the minimum value of $13.60 \mathrm{Kgs}$ and the maximum value of $48.10 \mathrm{Kgs}$. While the mean weight of boys was $25.27 \mathrm{Kgs}$ ( $\pm S D$ 6.17) and in girls the mean weight was $26.83 \mathrm{Kgs}( \pm S D 7.03)$. Total of study population were 5-10 years (whom WA z-score are available in WHO References 2007), 46 (18.3\%) were underweight. Gender wise underweight was more seen in girls $18.7 \%(20)$ than in boys $17.9 \%(26)$. Thinness (BMl for age) was seen normal in $86.3 \%$ (364) and in $13.7 \%$ (58) thinness was present, out which $4.5 \%$ (19) were severely thinned.Regarding to illness in last year $341(80.8 \%)$ were replied yes, and $81(19.2 \%)$ said that, they were all right. The Mean BMI in the subject population was $15.42( \pm S D 2.02)$ with the minimum value of 10.70 and maximum of 25.60. Boys were having the average of $15.30( \pm S D$ 1.84 ), while girls were at the average of 15.53 . The physical examination revealed that, the prevalence of Pallor in the study population was $25.8 \%$ (109). Xerosis was present in $5.5 \%$ (23). Bitot's spots were observed in $2.6 \%$ (11), Koilonychia was absent in all $422(100 \%)$ pupils, 33.9\% (143) were having Dental caries, Mottled enamel was seen in $23.2 \%$ (98) participants and BCG vaccination mark was present in $59.2 \%(250)$ students (table 3 ). 
Table 2: Sociodemographic characteristics of the study participants

\begin{tabular}{|c|c|c|}
\hline Variables & & \begin{tabular}{|l}
$\begin{array}{l}\text { Percentage } \\
\text { (numbers) }\end{array}$ \\
\end{tabular} \\
\hline \multirow[t]{2}{*}{ Child's father education } & Literate & $316(75)$ \\
\hline & Illiterate & $106(25)$ \\
\hline \multirow[t]{2}{*}{ Child's Mother education } & Literate & $190(45)$ \\
\hline & Illiterate & $232(55)$ \\
\hline Monthly income & 14681.27 Mean & $(422)$ \\
\hline \multirow[t]{4}{*}{ Age } & $5-6$ years & 16 \\
\hline & $7-8$ years & 112 \\
\hline & $9-10$ years & 124 \\
\hline & $11-\geq 12$ years & 170 \\
\hline \multirow[t]{4}{*}{ Age group wise mean weight } & $5-6$ years & 16 \\
\hline & $7-8$ years & 112 \\
\hline & $9-10$ years & 124 \\
\hline & $11-\geq 12$ years & 170 \\
\hline \multirow[t]{2}{*}{ Under weight Children } & Boys & $17.9(26)$ \\
\hline & Girls & $18.7(20)$ \\
\hline \multirow[t]{2}{*}{ Thinness BMI for age } & Present & $13.70(58)$ \\
\hline & Absent & $86.30(364)$ \\
\hline \multirow[t]{2}{*}{ Illness in last year } & Reported ill & $81(341)$ \\
\hline & All right & 19(81) \\
\hline \multirow[t]{4}{*}{ Age wise stunting } & $5-6$ years & 5 \\
\hline & $7-8$ years & 23 \\
\hline & $9-10$ years & 23 \\
\hline & $11-\geq 12$ years & 52 \\
\hline
\end{tabular}

Pallor was more observed in 5-6 years age group 56\% and in $11-\geq 12$ years age group $30 \%$. Dental caries were also more seen in 5-6 years (43\%) and were less seen in $11-\geq 12$ years (28\%). BCG vaccination mark was present higher in 5-6 years $75 \%$ as comparatively was less in $11-\geq 12$ years age group.Stunting was statistically significance in girls (9-10 years) 16 , out of 58 girls were stunted ( $p$ value $=.015, \mathrm{Cl}: .118-.823$ ) as compare to boys, who were 7 , out of 66 were stunted. Stunting was also statistically significant in girls (11$\geq 12$ years) present in 37 , out of 98 ( $p$ value $=.018, \mathrm{Cl}$ : $.215-.874$ ) as 15 out of 57 were having stunting. Thinness or BMI for age was also significance who were doing insufficient breakfast as 57 out of 347 were having <-2 SD BMl for age ( $p$ value $=.002$. Cl: .033-.584) as who were doing sufficient breakfast seen in 2 out of 75 (table-2). Stunting was seen significantly associated in 97 out of 347, who were doing insufficient breakfast ( $p$ value $<.001, \mathrm{Cl}$ : .094.533) as compare to sufficient breakfast, in which 6 were stunted out of 75.Prevalence of Stunting $(\mathrm{HA})$ in study population was present in $103(24.4 \%)$. Gender wise prevalence of stunting of boys was seen in $18.9 \%(41)$, but in girls stunting was present in $30.2 \%$ (62), which is statistically significance ( $p$ value $=0.007$, Cl:.384-.844).

Table 3: Gender wise distribution between boys and girls

\begin{tabular}{lccc}
\hline Physical examination & Goys & Girls & p value \\
\hline & 37 & 72 & $<.001^{*}$ \\
Pallor & 9 & 14 & 0.225 \\
Xerosis & 7 & 4 & 0.411 \\
Bitot's spots & 0 & 0 & \\
Koilonychia & 88 & 55 & $0.003^{*}$ \\
Dental caries & 60 & 38 & $0.027^{*}$ \\
Mottled enamel & 116 & 134 & $0.013^{*}$ \\
BCG mark & & &
\end{tabular}

Mean height of study population was $129.19 \mathrm{~cm}$ $( \pm S D 12.74$ ) with the minimum height of $95.00 \mathrm{~cm}$ and the maximum height of $167.10 \mathrm{~cm}$. In the Boys Mean height was $128.09( \pm S D 12.90)$ and in Girls the value of Mean height was 130.36 ( \pm SD 12.50). The age group wise Mean height is given in Table: 9 .

Dietary Practices:

Breakfast was categorized in two, one was sufficient breakfast consisting; egg, cereals, bread/roti, tea. And second category insufficient breakfast had; Rusk/biscuits, roti/bread and tea. $75(17.8 \%)$ were doing sufficient breakfast and $347(82.2 \%)$ were doing insufficient breakfast. 21.2\% (46) boys were doing sufficient breakfast and $78.8 \%$ (171) were on insufficient breakfast. In girls $85.9 \%$ (176) were doing insufficient breakfast and $14.1 \%$ (29) were doing sufficient breakfast.Eating fruits regularly were told by $364(86.3 \%)$ either bought by themselves or brought by their parents and $58(13.7 \%)$ were denied to eat fruits. $276(65.4 \%)$ replied yes to drink milk regularly especially before sleeping at home and 146 (34.6\%) did not drink milk because of reasons, more common was their parents/caregiver could not afford it.

\section{Discussion}

Study has observed most of the students were having late enrolment in all four Government primary schools which were included in the study. Study shows with similar findings [5]. The socio demography of Bangladesh is almost same as in context of Pakistan so there were almost same findings of stunting seen as in present study $[6,7,8]$. A community based survey was conducted among school going children in Addis Ababa Ethiopia. Results showed $19.6 \%$ and $15.9 \%$ were stunted and underweight respectively. That findings near to our study findings although in Ethiopia poverty and food security are problems but in our study low socio economic status might be cause of same findings. In above said study underweight increase significantly with an increase in age, family size, and order of birth and in the absence 
of hand washing facility $[9,10]$. As study conducted among primary school going children of Lahore aged 5-12 year were participated in that study, $32 \%$ children were found under nutrition or thin [11]. A study done on prevalence of malnutrition among primary and secondary school children in Bangalore, India $[12,13,14]$. After seven days trail order was reversed, results of measurement of cognitive function showed self reported alertness improved significantly in whole study population, and male participants were feeling more positive after eating breakfast [15]. Physical examination of pupil revealed that pallor was more in girls $17 \%$. Bitot's spots and dental caries were more in boys $11.3 \%$ and $20.8 \%$ respectively. In NNS 2011 $62 \%$ children are anemic under five which more than double as in study pallor was seen in $25.4 \%$. According to NNS-2011, nutritional status is slightly better in urban areas as compare to rural areas and boys are better with their nutritional status than in girls. Regarding PDHS 2012-13 food security, poverty and illiteracy in women are main factors in malnutrition.

\section{Conclusion}

The study concludes that nutritional status of government primary school going children was not good enough as stunting, underweight and thinness is $24.4 \%, 15.3 \%$ and $13.7 \%$ respectively. Late enrolment of students in all four government primary schools was seen particularly in girls, whom mean age was 118.09 months ( \pm SD 27.78). Pallor was present more in $72(35.1 \%)$ girls. BCG vaccination mark was present in just more than half of the students $(59.2 \%)$. Other contributing factors in malnutrition like low socio-economic status, illiteracy in parents, dietary pattern, food insecurity, poor health services and lack of micronutrients are major problems.

\section{References:}

1. Shivaparkash NC, Joseph RB. Nutritional Status of Rural School Going Children (6-12 Years) of Mandya District, Karnataka. International Journal of Scientific Study.2014; 2 :(2).

2. Moushagan NGT, Kujinga P, Chagwena D.T, Chituwu R, Nayabanga G. A Restrospective Study of the Nutritional Status of Primary School Children In Harare. Ajfand. 2014; 14:(03).

3. Izharul $\mathrm{H}$, et al,An Assessment of Nutritional Status of the Children of Government Urdu Higher Primary Schools of Azad Nagar and its Surrounding Areas of Bangalore.Archives of Applied Science Research. 2011; 3 (3):167-176.

4. Mondal T, Mondal S, Biswas M. An Assessment of Nutritional Status of Children of Government Aided Primary School of West Bengal. International Journal of Elementary Education.2014; 4(3):41-45.

5. Siddique S, Ayub M, Shore N, Tariq U, Zaman S. Nutritional Status of Primary School Children in Abbottabad. J Ayub Med CollAbbottabad. 2013;25(1-2).
6. Amare B, Moges B, Fantahun B et al. Micronutrient Level and Nutritional Status of Children Living in North West Ethopia. Nutri J.2012;11: 108.

7. SangwanL, Kumar R, Arun $P$ et al. Anthropometric Characteristics and Nutritional Status of Primary School Children in Fatehabad City Haryana. Int J B \&Appl Sci:2014; 4(2).

8. Rashmi M R, Shweta B, Fatimah $\mathrm{F} \mathrm{N}$ et al. Prevalence of Malnutrition and Relationship with Scholistic Performance among Primary and Secondary School Children in Two Selected Private Schools in Banalore Rural District, India. Indian J Community Med. 2015;40 (2): 97-120.

9. Ara R, Houque S R, Adhikary M et al. Nutritional Status Among the Primary School Children in Selected Rural Community, J Dhaka Med Coll. 2001;20(1): 97-101.

10. Müller $\mathrm{K}$ W, Hille $\mathrm{K}$, Klenk $\mathrm{J}$ et al. Influence of Having Breakfast on Cognitive Performance and Mood in 13-to 20-Year-Old School Students: Result of a Crossover Trail. Ped J AAP. 2015; Vol $122(2)$.

11. Khan T, Khan EA, Raza M A. Gender Analysis of Malnutrition: A Case Study of School Going Children in Bhawalpur. Asian development policy review J. 2015; 13(2):29-48.

12. Degarege $D$, Degarege A, Animut A. Undernutrition and Associated Risk Factors among School Age Children in Addis Ababa, Ethiopia. BMC Public Health J. 2015;15:375.

13. Bernardo C, Pudla K et al. Factors Associated with Nutritional Status of 7-10 Year-old School Children: Sociodemographic Variables, Dietary and Parental Nutritional Status.2012;15(3):65161.

14. Mishtaque M, Gull S, Shahid U et al. Familybased Factors Associated with Overweight and Obesity among Pakistani Primary School Children. BMC Pediatrics J. 2011;11:114.

15. Ashok N C, Kavitah H S, Kulkarni P. A Comparative Study of Nutritional Status between Government and Private School Children of Mysore City. Int J Health \& Allied Sci. 2014;3(3): 164-169. 